\title{
O QUE É UM ABORÍGENE? MODOS DE CATEGORIZAÇÃO RACIAL NO SUDESTE DA AUSTRÁLIA
}

Bastien Bosa

Para Lygia Sigaud, a quem revi em Bogotá, em novembro de 2008. Sua elegância, seu entusiasmo e seu rigor nos farão falta.

L'autisme n'est pas seulement une espèce de trouble du comportement: c'est aussi une catégorie administrative (Ian Hacking).

Oxford, England

The Dean of Worcester College has found an unusual way of getting around the ancient rules that bar dogs from his college. The governing body voted last week that his dog, Flint, is a cat (San Francisco Chronicle, 10 novembre 1975 apud Dominguez 1994:v).

Legal status is not merely a juridical fiction - an imaginary chart of possible positions. Rather - this is why law is so crucial for any analysis of the production of social categories - legal status is constitutive of lived communities, insofar as it organises access to institutions (E. Saada 2002:108).

Se quisermos definir a estrutura racial das New South Wales (NSW) nos anos 1950, será preciso começar pela seguinte questão: quem era considerado aborígene, tanto nas práticas cotidianas de categorização quanto pela lei? Imediatamente, temos aí um paradoxo. De maneira geral, o sistema de classificação racial no Sudeste da Austrália seguia uma distinção bipartida, opondo aqueles que tinham uma origem "aborígene" conhecida e os demais. Tomando em consideração algo como uma one drope rule ${ }_{1}^{1}$ o conhecimento de um único ancestral aborígene já era suficiente para ingressar na categoria "negro", em oposição ao resto da sociedade australiana, tida como "branca".2 No entanto, esta potente dicotomia não parecia sustentada por um aparelho 
jurídico-burocrático muito sólido: veremos, de fato, que as NSW eram caracterizadas pela existência de uma "categorização flutuante" (ligada à presença, na lei, de duas definições "oficiais" parcialmente contraditórias) e pela ausência de técnicas de identificação que permitissem "capturar" os indivíduos por "escrito" (como a carteira de identidade). Mostraremos, no entanto, que se estas técnicas de identificação, frequentemente lacunares, certamente permitiram a alguns passar através das malhas do sistema identificatório, de maneira geral, elas não recolocaram em questão a existência de um sistema de relações raciais fortemente dicotômico. Tratar-se-á, portanto, por um lado, de ressaltar o interesse que há - ao se trabalhar com práticas de identificação em não se limitar aos textos gerais ou aos discursos; e de lembrar, por outro lado, que se as formas de classificação racial são contingentes e arbitrárias, nem por isto elas são instáveis ou desprovidas de efeitos sociais.

\section{Quadro 1}

A Austrália é, desde 1901, um Estado Federal que engloba seis Estados (New South Wales, Victoria, Queensland, South Australia, Western Australia, Tasmania) e dois Territórios (Northern Territory e Australian Capital Territory).

Em virtude de uma divisão muito estrita instituída pela constituição australiana, o governo federal (também chamado de Commonwealth), até 1967, só tinha responsabilidade pelos Assuntos Aborígenes no Território do Norte. Cabia, portanto, a cada Estado gerir sua população aborígene, seguindo legislações particulares. Os fatos aqui apresentados ocorrem em um único Estado especificamente: New South Wales (NSW); em francês, Nouvelles Galles du Sud.

A participação do Estado nos assuntos aborígenes nas NSW começou com a criação do Aboriginal Protection Board, em 1883. Durante esses primeiros anos de existência, entretanto, este último não tinha uma missão bem definida (com exceção da vigilância das atividades das igrejas e da distribuição de rações de comida) e pouco poder.

A situação modificou-se com a adoção do Aboriginal Protection Act - APA, em 1909, que conferia poderes estatutários ao Aboriginal Protection Board e lhe confiava a responsabilidade por todas as reservas aborígenes. O APA impunha particularmente certas restrições sobre a movimentação dos aborígenes, 
proibindo-os de consumir álcool e estabelecendo certas disposições sobre "o controle da aprendizagem das crianças aborígenes". Graças a certo número de emendas no APA, o Board estendeu progressivamente seus poderes, arrogandose particularmente o direito de retirar crianças de suas famílias (no intuito de facilitar sua assimilação na comunidade).

Uma reviravolta importante ocorreu em 1940, momento em que o Board foi rebatizado de Aboriginal Welfare Board. Ao APA foram novamente introduzidas emendas (embora de modo relativamente marginal) e o Board reivindicou abertamente uma política visando à "assimilação" dos Aborígenes na comunidade. O relatório anual de 1945 explicava assim, com orgulho, que o objetivo do Board era, dali por diante, o de "preparar os povos aborígenes para a cidadania" e que tudo seria feito "para instruir as pessoas de pele escura e permitir que se ajustem ao modo de vida do homem branco" (AWB Annual Report, 1945).

Apesar desta passagem de uma retórica do "controle" a um discurso que insiste fortemente na necessidade "de ajudar e encorajar" os aborígenes, estes últimos permaneciam como uma população intensamente vigiada, em particular devido a um aumento da burocratização trazido pelo Board. Decidimos centrar a discussão nos modelos e nas práticas identificatórias que caracterizam o Sudeste da Austrália durante os anos 1950, em função de esse período corresponder a um momento de "rotinização" e de estabilização da dominação colonial.

\section{"Who is black?": classificações práticas e jurídicas}

\section{A definição "comum"}

A existência de um sistema binário que opunha os "Brancos" (isto é, as pessoas de origem exclusivamente europeia) e os "Negros" (isto é, as pessoas que tinham uma ascendência aborígene conhecida) aparece claramente nos relatórios de uma equipe de antropólogos da Universidade de Sydney que fizeram pesquisas sobre as relações inter-raciais em diversas regiões das NSW nas décadas de 1950-1960. ${ }^{3}$

Em geral, tais trabalhos chegavam às mesmas conclusões. Jeremy Beckett (1965:2-3), cujas pesquisas desenvolviam-se no Far-West das NSW, assim explicava: 
A distinção importante se faz entre aqueles que têm uma origem aborígene e aqueles que não a têm. Alguns não podem ser distinguidos fisicamente, mas conservam uma identidade aborígene [...] As gradações de cor não têm importância.

Mary Reay (1949:93), que realizou suas pesquisas na cidade de Moree, no Noroeste do Estado, chegou à mesma constatação. Ela observou que a "opinião branca" enquadrava "todas as pessoas com qualquer grau de descendência aborígene" na categoria black, o que confirmava, segundo ela, a ausência de "termos específicos que permitissem diferenciar os mixed-bloods das pessoas com uma ascendência aborígene pura". Ruth Fink (1957:105), uma antropóloga que trabalhou em Brewarrina, confirmou que os "brancos" geralmente não faziam distinção entre as half-castes ${ }^{4} \mathrm{e}$ os full-bloods e, quando o faziam, era frequentemente em detrimento das primeiras:

Para os Brancos, as pessoas de cor são todas iguais. Eles as classificam todas como negras. O policial da região declarava, por exemplo: "As half-castes são um grupo ruim, pois eles herdam o que há de pior do sangue branco, nenhum dentre eles tem valor".

Os antropólogos de Sydney elaboraram coletivamente o conceito de caste-barrier para descrever esta situação (amplamente conhecida sob a denominação colour-bar ou colour line). Jim Bell (1965), antropólogo cujo campo estava situado na costa sul do Estado, propunha a seguinte definição:

A caste barrier é um ponto arbitrário na hierarquia social acima do qual os membros da casta mais baixa, neste caso os part-Aborigines, não são aceitos, quaisquer que sejam suas realizações. Eles não podem participar das atividades sociais da casta superior, neste caso, os Europeus da região [...]

Muito poucos europeus estão dispostos a estabelecer relações sociais com pessoas de cor, com medo de serem alvo de uma condenação pública (Bell apud Fink 1957:101).

Nesta lógica, como explicava Malcolm Calley (1957:190), cujas pesquisas eram desenvolvidas na costa norte das NSW, os aborígenes estavam relegados a um estatuto "inferior àquele mais baixo dos homens brancos" no seio da hierarquia social. De fato, o pertencimento ao grupo "aborígene" não estava ligado à cor ou à suposta "casta" dos indivíduos, nem à sua "cultura" ou "tradição", mas sim diretamente associado a uma experiência histórica comum de segregação e despossessão.Esta "unidade" de todos 
os Aborígenes, qualquer que seja sua cor de pele, é confirmada de modo muito claro pelos discursos de militantes aborígenes do final dos anos 1930 . Por ocasião de um "Dia de Luto", organizado em 1938 em protesto contra os 150 anos da invasão dos ingleses, William Fergusson, um dos principais dirigentes aborígenes, declarou :

Todos os homens e mulheres de sangue aborígene são concernidos pela discussão que travamos hoje. Mesmo se alguns são escuros e outros claros, nós somos todos classificados como aborígenes pela legislação atual ("Day of morning", The Abo Call, julho 1938:2).

De modo muito similar, outro desses líderes, William Cooper, havia escrito pouco antes ao Ministério do Interior do Commonwealth:

Se vocês observarem os problemas que são os nossos, do ponto de vista indígena, esqueçam por favor a discriminação feita pelo homem branco entre a half-caste e o full blood. [...] Todos são aborígenes e felizes de o serem, orgulhosos de o serem (NAA(CO), A659, 1940/1/858). ${ }^{5}$

Último exemplo: o jornal Abo Call, do militante Jack Patten, insistia na mesma época sobre o fato de que a categorização atingia todas as pessoas que tinham origem aborígene:

De acordo com a legislação das NSW, toda pessoa que tiver uma proporção qualquer de sangue aborígene entra na definição de Aborígene, e aqueles que são submetidos a estas leis são objeto de uma discriminação política e estão submetidos a desvantagens sociais e econômicas cujo objetivo é o de levar à sua exterminação final (The Abo Call, agosto de 1938).

\section{Aboriginal by law: a classificação legal da raça nas NSW}

Como sugerem estas declarações de militantes aborígenes da primeira metade do século XX, o pertencimento a um grupo ou a um coletivo particular só faz sentido em um quadro estatal específico. Tratar-se-á, portanto, de colocarmos a seguinte questão: quem era, de um ponto de vista estritamente legal, aborígene nas Novas Gálias do Sul? ${ }^{6}$

De modo surpreendente, constata-se a existência de uma importante divergência entre a definição "comum", que acabo de descrever, e a definição legal tal como aparece na legislação que fixava o estatuto das populações 
aborígenes e os procedimentos para controlá-las: o Aboriginal Protection Act (1909-43). ${ }^{7}$ De fato, nas NSW, como em todos os outros Estados australianos, o principal critério de identificação dos aborígenes era o "sangue", e esperava-se que a inclusão ou a exclusão refletisse um quantum de sangue "negro": a definição oficial considerava assim como aborígene "qualquer full-blooded ou half-caste aborígene nativo da Austrália e que esteja residindo nas NSW temporariamente ou em caráter permanente". ${ }^{8}$ Ora, a expressão half-caste designava, no contexto jurídico australiano, as pessoas que tinham "ao menos 50\% de sangue aborígene". Em consequência, aqueles que, segundo este tipo de cálculo "antropológico-matemático" eram "menos que half-castes", em teoria, não deveriam ser considerados como Aborígenes, quando na realidade - se acreditarmos nos trabalhos dos antropólogos da Sydney School - era este o caso nas interações cotidianas.

De fato, um exame mais detido da lei indica que ela continha uma outra definição, não somente de mais fácil aplicação, como também muito mais extensiva. Esta segunda definição enquadrava como Aborígene "qualquer pessoa que aparentemente tivesse uma mistura de sangue aborígene" (APA 1909). À diferença da primeira, ela coincidia com a definição "comum" e confirmava a dicotomização da população nas NSW: qualquer pessoa que tivesse uma ascendência aborígene conhecida ou visível era considerada "negra". 9

De maneira geral, a partir dos primeiros anos do século XX, parece ter havido a transição de uma definição jurídica restritiva (incluindo unicamente aqueles chamados full-bloods) em direção a uma definição mais ampla, que incluiria, ao contrário, todas as pessoas que possuíssem uma origem aborígene. Assim, em 1903, um juiz declarou a propósito do NSW Liquor Act de 1898 (que proibia os Aborígenes de consumirem álcool) que um "pequeno vestígio de sangue branco" seria suficiente para que a pessoa não fosse incluída na categoria "aborígene" (Cf. Chesterman et alli 1998:134). Dois anos mais tarde, em 1905, quando o Parlamento das NSW emendou este mesmo Liquor Act, ele introduziu, por solicitação do Aboriginal Protection Board, a expressão "tendo uma mistura de sangue aborígene". ${ }^{10}$ Nem por isso a mudança foi tão radical quanto poderíamos pensar, na medida em que somente se esperava aplicar esta nova definição de nativo aborígene às pessoas que recebessem uma assistência do Aboriginal Protection Board (particularmente "rações de comida" ) ou que residissem nas reservas aborígenes. ${ }^{11}$

Neste sentido, a definição do estatuto de uma pessoa não mais dependia exclusivamente da quantidade de "sangue" aborígene nela existente, mas igualmente de seu modo de vida. Esta definição foi retomada na APA de $1909^{12}$ mas, após uma emenda em 1918, as referências às "rações de comida" e à residência nas "reservas" foram suprimidas. ${ }^{13}$ Portanto, somente 
subsistiu na legislação a dimensão propriamente racial das duas definições parcialmente contraditórias (uma incluindo somente os full-blooded ou half-caste aborígenes, a outra, todos aqueles que tivessem "uma mistura aparente de sangue aborígene"). ${ }^{14}$ O Public Service Board, que produziu um relatório sobre a administração dos assuntos indígenas em 1938, ressaltou a contradição entre as duas definições, mas esta última não foi suprimida do novo APA, adotado em 1940. ${ }^{15}$

De um ponto de vista prático, era à definição mais ampla que o Board fazia referência em seu trabalho cotidiano. Por ocasião dos debates parlamentares de 1936, na preparação das emendas ao APA, um deputado explicava que a intenção original do legislador era a de se ocupar somente dos full-bloods, mas que durante o processo de elaboração das emendas uma definição muito ampla acabou sendo adotada:

A lógica da lei era a de que como os full-blooded aborígenes estavam em vias de extinção, o Governo considerava que os quadroons e os octoroons não eram de responsabilidade do Estado. Considerava-se que se eles fossem retirados das missões e de reservas aborígenes e enviados a ocuparem-se de seus assuntos e a ganharem suas vidas, o problema desapareceria. Uma emenda foi adotada, no entanto, ampliando a definição de "aborígene" para incluir qualquer pessoa que tivesse sangue aborígene correndo em suas veias. Isto estava em contradição com o objetivo inicial da lei e o resultado é que, hoje em dia, o número destes quadroons e octoroons no Estado é maior do que aquele anterior de aborígenes (AP(A)B, 23 de junho de 1936, segunda leitura ). ${ }^{16}$

Observaremos, para além disto, que se certos agentes do Board demandavam de tempos em tempos uma aplicação "mais estrita" da definição, mas suas demandas eram ignoradas de maneira quase sistemática. Por exemplo, H. J. Green, enquanto era Welfare Officer estagiário, escreveu sobre a estação de Cowra, em um relatório para o Board, que a maioria de seus residentes tinha uma cor de pele "tão clara" que não era razoável autorizá-los a residir em uma "estação ou reserva". No entanto, como na maioria dos outros casos que encontramos, o Board não levou em conta sua solicitação. ${ }^{17}$

\section{Como reconhecer um Aborígene?}

Uma coisa é propor uma definição estável para uma dada população, outra é conseguir colocar em prática esta mesma definição. Ainda existem, neste sentido, divergências mais ou menos importantes entre as práticas efetivas 
e os termos da lei, e o pesquisador deve assim situar no centro de suas análises as interações entre as administrações e as pessoas classificadas, ao invés de trabalhar unicamente a partir das definições "oficiais" ou de uma história puramente institucional. No caso que aqui nos interessa, uma das dificuldades se devia ao fato de não haver nem uma lista exaustiva, nem documentos pessoais de identidade especificamente emitidos pelo Estado que permitissem identificar a população aborígene. ${ }^{18}$

Para além disso, quando em meados do século XIX o governo das NSW instaurou um sistema secular de Estado civil do qual se esperava que fossem aplicados de modo universal os colonial subjects do Estado (do qual faziam parte os Aborígenes), nenhuma forma de categorização racial foi incluída. Em consequência, nada distinguia os Aborígenes do restante da população nas certidões de nascimento, de casamento ou nos atestados de óbito. Mesmo que, na prática, alguns oficiais de registro civil se dessem ao trabalho de incluir a menção "Aborígene" (ou um equivalente) ao lado do nome, esta prática era originária de sua própria iniciativa, nada tendo de sistemática. ${ }^{19}$ Resulta daí o fato de que numerosos aborígenes tenham sido incluídos nos registros estatais sem que uma menção especial permitisse distingui-los. Além disso, como a quase totalidade dos Aborígenes do Estado havia adotado nomes europeus desde o final do século XIX, em geral eles não eram identificáveis como tais de um ponto de vista administrativo. ${ }^{20}$

Os procedimentos de identificação repousavam, portanto, amplamente sobre a aparência física, a reputação individual e as interações face a face entre as populações aborígenes, os funcionários e os poderes locais (administradores, policiais, magistrados, professores etc.). ${ }^{21}$ Uma mudança legislativa de 1936 levou esta lógica identificatória ao extremo, decretando que seria suficiente que uma pessoa fosse "considerada" como "aborígene" por um magistrado para que caísse nas malhas do APA.

18b. Em qualquer procedimento ou enquete jurídicos, seja no contexto da aplicação desta lei ou de qualquer outra, se o tribunal, o juiz, o coroner ou o magistrado [...], após ter visto uma pessoa que mantém, de uma forma ou de outra, uma relação com o procedimento ou a enquete, ele pode determinar se esta pessoa é ou não aborígene em função de sua própria opinião (AP(A)A, 1936, artigo 18b). ${ }^{22}$

Durante o debate que precedeu a votação, os deputados trabalhistas opuseram-se a esta emenda, estimando que ela era contrária aos princípios da justiça britânica: segundo eles, a reforma voltava a "considerar que um homem é culpado a menos que prove sua inocência". ${ }^{23} \mathrm{O}$ deputado Davidson foi ofuscado. 
Não é verdadeiramente justo, por assim dizer, colocar o fardo sobre o acusado para decidir se é um aborígene ou não. Muito em breve, o Governo irá pedir a estas pessoas que compareçam ao Departamento e Registro Geral para obter uma cópia de sua certidão de nascimento, que é a atitude do Governo atualmente para ganhar dinheiro no caso dos estudantes que queiram obter reduções junto ao departamento das estradas de ferro (AP(A)B, 23 de junho de 1936, segunda leitura).

M. Bate, o deputado que defendia a emenda, respondeu que esta última era precisamente necessária porque um advogado tinha ressaltado ao Board que, na medida em que as certidões de nascimento não registravam a raça, era impossível para o Board provar que uma pessoa era aborígene.

Por ocasião de um negócio, um advogado muito esperto explicou que o Board não podia provar que uma pessoa era aborígene e nós percebemos que ele tinha razão, já que quando produzimos a certidão de nascimento da pessoa em questão, nada havia que indicasse ser o homem aborígene (AP(A)B, 23 de junho de 1936, segunda leitura). ${ }^{24}$

A emenda foi votada, permitindo aos membros do Board (mas igualmente aos tribunais) gozarem de uma grande flexibilidade: eles tinham agora a possibilidade de mudar suas práticas sem precisar modificar a definição oficial, já que uma pessoa era "aborígene" a partir do momento em que um juiz a considerasse como tal. O Board, portanto, tinha a garantia de que a definição legal sempre correspondia às práticas correntes de identificação. Por exemplo, em 1961, o advogado de um dono de bar, acusado de ter servido álcool a um aborígene (o que era proibido pela APA), observou que não havia qualquer prova indiscutível de que seu cliente possuísse uma "mistura de sangue aborígene" (Wellington Times, 14 de junho de 1961). Ele declarou:

A única prova de que se trata de um aborígene half-caste é a declaração dos policiais [...] Há muitas pessoas de pele morena na comunidade e não são todos aborígenes. Não é suficiente para submetê-lo às regras do APA (Ibidem).

Graças à emenda de 1936, a Police Prosecutor respondeu, entretanto, que este argumento não era admissível: o APA aplicava-se a qualquer pessoa que tivesse "aparentemente uma mistura de sangue aborígene", e não era incumbência do tribunal fornecer a prova de que o acusado era aborígene: "Se, após tê-lo visto, o tribunal considerar que ele tem sangue aborígene, é uma prova suficiente" (Ibidem) ${ }^{25}$ 
Este sistema permite assim explicar o fato de que, a despeito desta incerteza da definição, quase não tenha havido litígios jurídicos sobre tais questões (ao menos no caso das NSW): na ausência de documento escrito apoiando a categorização, qualquer pessoa que desejasse contestar a classificação aborígene que lhe fosse atribuída recebia como resposta que cabia ao juiz e somente a ele decidir sobre esta questão.

\section{A dificuldade em lidar com as definições raciais}

Enfim, a adoção de uma ampla definição administrativa não correspondia simplesmente ao desejo de fazer coincidir definição jurídica e senso comum, mas igualmente se explica pelo caráter não-manejável das definições raciais "científicas" e pela dificuldade de estabelecer distinções claras entre os grupos. Em 1942, o Board explicava, por exemplo, que uma definição satisfatória dos chamados half-caste era difícil de ser encontrada, já que o pertencimento a esta categoria reenviava raramente a uma definição estritamente racial ("Ela pode incluir os 3/4-caste, os quarterons, ou mesmo os octorons" [AWBAR 1942]).

A partir dos anos 1930, os antropólogos elaboraram tabelas complexas que deveriam permitir estabelecer com precisão o "grau de sangue aborígene" de um dado indivíduo. No entanto, o uso administrativo destas tabelas era geralmente fastidioso, e os próprios antropólogos nem sempre estavam convencidos da possibilidade prática (nem mesmo do interesse) de se estabelecer a "casta" precisa de um dado indivíduo. Uma carta escrita em 1944 pelo antropólogo e membro do Board A. P. Elkin a J. Carrodus, ministro dos Territórios (Commonwealth), ilustra o absurdo dessas classificações:

Mesmo que as definições de half-blood e de quadroon não sejam idênticas, elas coincidem; as dificuldades aparecem no caso das pessoas que são 3/8 aborígenes, isto é, que têm três bisavós aborígenes. Esta pessoa deve ser chamada de quadroon ou de half-caste? Ou será preciso inventar um novo termo? [...] Vocês observarão que eu sugiro, no caso do quadroon, que normalmente esta pessoa deveria ter dois bisavós full-blood aborígenes e que, em todo caso, esta pessoa seria menos de 50\% aborígene [...] Evidentemente, se a lei fosse modificada e se quiséssemos mais precisão, poderíamos muito bem incluir na definição de quadroon as pessoas que são 3/8 aborígenes. Mas mesmo neste caso isto não é correto do ponto de vista matemático. Seria logicamente ideal, mas não muito prático, decidir cada caso em função de seus méritos: assim, um three-eights com 
a pele clara poderia ser classificado como um quadroon e um three-eights com a pele escura como um half-blood [...] Ao longo dos anos, as matemáticas irão se complicar ainda mais. Seremos confrontados então com os 1/16, mas é provável que, nesse momento, somente nos interessemos pelos full-bloods e pelos threequarter castes e que os half-castes e talvez os three-eights sejam considerados brancos (Carta de 07 de dezembro de 1944. Citada em Gray 1999).

Para resolver (provisoriamente) o problema, os funcionários do governo federal (Commonwealth) decidiram, na segunda metade dos anos 1960, que a ideia de "preponderância do sangue aborígene" seria "metafórica". No caso das NSW, o problema se colocou em 1961, quando um deputado (M. Wright, MLC) sugeriu ao Board lançar uma grande pesquisa a fim de determinar com precisão a "casta" de todos os Aborígenes do Estado (Board's minutes, 17 de outubro de 1961 -AWBGC, NSWAO, 8/2912B, 13991). O Board acolheu positivamente esta proposição e decidiu que os "antropólogos seriam responsáveis por esta pesquisa". No entanto, A. P. Elkin não estava presente por ocasião da reunião e, quando o Chairman o colocou a par desta proposição, ele declinou do convite, mesmo sendo uma boa oportunidade para obter financiamentos para seu Departamento.

Elkin justificou sua recusa explicando que uma pesquisa ${ }^{26}$ como esta seria não somente "longa e fastidiosa" mas também "muito incerta quanto à precisão dos resultados obtidos". Poderia ocorrer, por exemplo, que tal "aborígene não conhecesse a identidade de seu pai". ${ }^{27}$ O Board decidiu assim abandonar o projeto e contentar-se com as informações fornecidas anualmente pelos administradores das reservas relativas ao número e à "casta" dos residentes ("Full Blood, Half-Castes e outras castas - certamente des Lower Castes") (Board's minutes, 21 de novembro de 1961 - AWBGC, NSWAO, 8/2912B, 13991). Uma vez mais, vê-se como o aspecto lacunar das tecnologias administrativas de identificação (e sobretudo a ausência de uma tecnologia tão segura quanto a carteira de identidade) obrigava o Board a contentar-se com uma identificação face a face sob a responsabilidade dos administradores locais (Cf. Avanza \& Laferté 2005).

\section{Questão de recenseamentos}

Eu gostaria, agora, de ilustrar esta reflexão sobre a instabilidade dos procedimentos de identificação dos Aborígenes confrontando os números de três recenseamentos que contabilizaram a população aborígene das NSW, realizados em meados dos anos $1950 .{ }^{28}$ Os recenseamentos constituem de 
fato um dos meios mais visíveis de que dispõe o Estado para representar uma população (Kertzer et alli 2002:3). A primeira destas enumerações corresponde ao recenseamento organizado pela Commonwealth em $1954{ }_{i}^{29}$ a segunda foi organizada pela Aboriginal Welfare Board, em 1955; e a terceira foi levada a cabo pela polícia das NSW, em nome do Board, em 1957 (AWBGC, NSWAO, 8/2884B, 11412). ${ }^{30}$

À primeira vista os resultados parecem extremamente similares: cada um dos três recenseamentos indicou, com efeito, que as NSW contavam com pouco mais de 12 mil aborígenes. ${ }^{31}$ No entanto, a despeito desta aparente coerência, uma análise detalhada dos números nos convida a uma grande prudência. Não somente os inventários não cobriam a mesma superfície, como também, no âmbito local, as divergências encontradas foram significativas: por exemplo, alguns endereços mencionados em um recenseamento que supostamente incluía uma população aborígene importante eram ignorados em um outro e, frequentemente, as estimativas para uma mesma localidade diferiam de maneira significativa (portanto, é uma coincidência realmente extraordinária que os números totais terminassem por se equilibrar).

Parece que estas incoerências entre os números das três administrações podem ser explicadas precisamente pelo fato de que, na prática, o trabalho "de identificação" era complicado. Como já dissemos anteriormente, inexistiam "documentos de identificação aborígenes" emitidos pelo Estado ou pelo Commonwealth e tampouco havia uma lista exaustiva da população aborígene. Consequentemente, "a identificação" e a contabilização da população aborígene repousavam inteiramente na reputação individual e na identificação face a face. Ora, cada uma das administrações utilizava "técnicas de identificação" diferentes.

Assim, o Board e a polícia somente contabilizavam como "aborígene" as pessoas que eles "conheciam" efetivamente como tais. Isto significa que certo número de pessoas que se consideravam "aborígenes" (ou que eram consideradas como tais pelos vizinhos), mas desconhecidas dos serviços da polícia, não eram incluídas nas estatísticas. À diferença do Board e da polícia, o recenseamento do Commonwealth não se baseava unicamente em uma identificação "vinda de cima", incluindo também formas de "autoidentificação" (em particular, para os aborígenes que não viviam nas missões do governo). Contudo, isto não denota que todos aqueles que se consideravam aborígenes informassem automaticamente este fato aos agentes do recenseamento. Podemos então elaborar a hipótese de que muitos indivíduos que se consideravam, "na vida privada", "aborígenes", se recusassem a declará-lo ao governo, por medo de caírem nas malhas do APA ou de outras legislações repressivas. ${ }^{32}$ 


\section{Passar através das malhas da rede identificatória}

Em contradição (parcial) com a ideia de que o funcionamento dos sistemas coloniais necessariamente repousava sobre uma clara demarcação entre "colonos" e "indígenas", o caso do Sudeste australiano caracterizava-se, portanto, por uma dupla incerteza. ${ }^{33} \mathrm{~A}$ primeira, de um ponto de vista jurídico, dizia respeito à existência de duas definições contraditórias no APA: uma restritiva, incluindo somente os half-castes e os full bloods; a outra extensiva, incluindo todas as pessoas que tivessem uma origem aborígene conhecida. A segunda dizia respeito às técnicas de identificação que possibilitavam o funcionamento destas definições de forma prática: não existia nem uma lista exaustiva dos aborígenes, nem documentos de identidade a eles destinados e, oficialmente, a origem racial não era resgistrada em nenhum documento de estado civil. A identificação dos aborígenes repousava em grande parte, portanto, sobre a aparência física e a reputação das pessoas.

Para finalizar este artigo, gostaríamos de nos interrogar sobre os efeitos desta situação sobre a vida dos indivíduos: veremos que se ela inegavelmente permitiu a alguns escaparem de qualquer registro oficial e esconderem do Estado sua "ascendência" aborígene (contanto que não exibissem traços físicos que traíssem de modo inequívoco sua origem), tampouco impediu o funcionamento de um regime dicotômico de relações raciais.

\section{"Passar" por branco}

A maneira mais radical de mudar sua própria "identidade" era o "passing". ${ }^{34}$ Na medida em que, como vimos, não havia nem "carteira de identidade aborígene", nem uma listagem administrativa da população aborígene, podemos de fato imaginar que este era o meio mais seguro de gozar de maior liberdade e de escapar dos estigmas ligados à categoria aborígene (esta possibilidade somente estando aberta, evidentemente, àqueles que não pudessem ser facilmente distinguidos, de um ponto de vista físico, da população "branca").

\section{Desaparecer das listas eleitorais}

O caso de Ruth Olive McQuillan (nascida Miller) que solicitou sua exclusão das listas eleitorais do Board para a eleição dos representantes aborígenes de 1954 indica que era possível "desaparecer" das listas existentes. Ela escreveu: “Eu não vejo por que eu deveria votar no Aborigines Board porque sempre me disseram que eu não tinha sangue aborígene. Até onde eu sei, minha mãe é 
branca, meu pai é de origem indiana. Poderiam os senhores me informar o que eu deveria fazer, em caso contrário?".

Sem pedir maiores detalhes, o Board aceitou sua solicitação (13 de julho de 1954): "Como esta parece ser a sua solicitação, seu nome foi retirado da lista eleitoral". Eu não sei como a lista foi constituída (NSWAO, AWBGC, 8/2835, 7664).

Não houve um estudo preciso deste fenômeno na Austrália e não é fácil medir a frequência dessas formas de burlar a barreira categorial, na medida em que se tratava evidentemente de "um assunto secreto": na maioria dos casos, os indivíduos deviam "desaparecer" inteiramente do mundo aborígene do qual eram oriundos e recriar um ambiente inteiramente novo no qual qualquer informação a respeito de seu passado precisaria ser dissimulada. O processo era, portanto, custoso, tanto do ponto de vista emocional, quanto em termos de perda de laços afetivos. Qualquer contato com aqueles deixados para trás poderia, de fato, despertar uma suspeita, e a suspeita poderia levar a um retorno ao estatuto de aborígene.

Já há alguns anos, no entanto, tais casos de transferência para a comunidade branca começaram a ser destacados nos jornais. Estes exemplos podem, de fato, ser evocados publicamente num momento em que as barreiras raciais já não são tão fortes (ou melhor, num momento em que o fato de se declarar aborígene não mais acarreta consequências tão negativas). Uma história de passing foi publicada no jornal The Moree Champion durante a primeira semana de agosto de 1994 (Briggs-Smith 1997). Uma jovem mulher, Adeline Ann Duncan, abandonou a comunidade aborígene de Moree, em 1930, para se instalar em Sydney, fazendo-se passar por uma mulher branca e cortando todos os laços com seu passado aborígene. Ela deixou para trás sua filha, Rita Joan, que foi criada por seus avós. Em Sydney, casou-se com Ruben Browning, um rico homem branco, que ignorava tudo a respeito de sua origem aborígene e com quem teve uma outra fiha, Betty. Enquanto Rita foi inteiramente socializada na comunidade aborígene de Moree, Betty cresceu em Sydney, sem saber que tinha uma origem aborígene. O segredo foi revelado 64 anos mais tarde, quando as duas irmãs finalmente se encontraram.

Para além disto, existiam também formas mais "limitadas" ou "ocasionais" de franqueamento das fronteiras, também ligadas à ausência de documentos especialmente dedicados a identificar os aborígenes. Desta forma, na medida em que a identificação era incessantemente repetida e muito incerta fora dos círculos de interconhecimento, alguns podiam franquear temporariamente a Colour bar, fazendo-se passar, por exemplo, 
por maoris, malteses ou italianos. Isto lhes permitia, em particular por ocasião dos deslocamentos pelo interior do Estado, serem servidos em bares. O antropólogo Malcolm Calley (1957:199) explicava, por exemplo: "Os aborígenes de pele clara podem consumir álcool nas regiões onde não são conhecidos, às vezes, fazendo-se passar por 'malteses' ou por 'italianos', se forem perguntados a respeito".

O historiador Peter Read (1980) também dava exemplos semelhantes sobre trabalhadores da missão de Cowra que se faziam passar por maoris quando viajavam para outras cidades, de modo a serem servidos no pub (muitos homens aborígenes trabalhavam como guardadores de rebanhos). Um de seus pesquisados, Les Coe, assim explicava : "Fora das cidades, eu podia beber em qualquer hotel".

Último exemplo: o administrador da estação de Cabbage Tree Island relatava no início dos anos 1950 o caso de dois residentes desta estação que tinham aproveitado uma mudança de proprietário para serem servidos em um bar, no qual o serviço lhes era habitualmente recusado. No entanto, eles foram notados devido ao interconhecimento:

Em 14/07/1952, Lindsay e seu irmão William foram notados enquanto consumiam álcool no bar do Wardell Hotel. Este hotel tinha acabado de mudar de proprietário e os Combos aproveitaram para tentar tomar algo. O antigo proprietário, Mr. Stortenbecker, lhes pediu finalmente para deixarem o bar. ${ }^{35}$

Em outros casos, a transposição da "fronteira racial" era involuntária: alguns indivíduos normalmente considerados aborígenes podiam ser tomados por "brancos" sem mesmo se darem conta disto e, assim, tirarem proveito dos privilégios correspondentes. Em locais onde os indivíduos não eram conhecidos, a identificação se repetia em cada interação, e um dado indivíduo podia oscilar de um lado a outro, segundo os esquemas de percepção de seu interlocutor.

Um artigo do Herald de junho de 1955 narra da seguinte forma uma anedota muito significativa quanto ao tema da Colour bar na vila de Moree. Tomando o exemplo da piscina, o artigo sublinhava ao mesmo tempo a dificuldade dos empregados para detectarem nos clientes qualquer traço de origem aborígene, mas também o fato de que esta tarefa podia ser particularmente árdua:

Aqueles que se ocupam dos vestiários tornaram-se especialistas em reconhecer à primeira vista o menor traço de "cor" nos clientes. Eles ainda gostam de contar esta história em sua defesa: anos atrás, dois meninos pequenos se apresentaram 
na entrada dos vestiários. Um deles era negro, mas o outro parecia branco. O garoto de cor teve sua entrada negada, enquanto o outro garoto disse: "mas ele é meu irmão" (Herald, 25 de junho de 1955, "Colour Bar").

No entanto, qualquer que fosse a frequência desses casos de passing, eles não significavam de modo algum um questionamento da Colour bar e da ordem dicotômica das relações raciais (Dominguez 1994:xiv). ${ }^{36}$ Como vimos, aqueles que tentavam "passar" de modo permanente estavam condenados a cortar qualquer laço com a família e os amigos deixados para trás. Consequentemente, ao mudarem de categoria, mais do que contestar a dicotomia, eles a reforçavam.

Do mesmo modo, aqueles que passavam de modo "temporário" aproveitavam em geral esta situação em lugares onde não eram conhecidos para se beneficiarem dos privilégios que não lhes eram concedidos em circunstâncias normais. Esta aceitação se dava, portanto, com base em um mal-entendido, sendo, de forma evidente, de caráter extremamente provisório.

Neste sentido, a dupla incerteza que descrevemos não significava que a categoria "aborígene" não constituísse um constrangimento. Se ela permitiu a um número limitado de indivíduos, de modos diversificados, a transposição da "fronteira racial", de maneira geral, esta última era claramente desenhada e permaneceu relativamente estável ao longo do século XX. Como dissemos, o Board utilizava a definição mais extensiva em seu trabalho cotidiano e esta última prevalecia na vida social: de forma ampla, todas as pessoas que tinham uma origem aborígene conhecida eram, portanto, consideradas "negras".

A este respeito, elas eram habitualmente objeto de formas diversas de exclusão: uma segregação geográfica (os aborígenes moravam com frequência em reservas ou nos campos nas periferias das cidades), a exclusão da vida social (dos pubs, dos cinemas, das piscinas etc.), de serviços diversos (escolas, hospitais, igrejas) e, por fim, a segregação no trabalho (pelo acantonamento em certas profissões). ${ }^{37}$ Consequentemente, convém não se colocar de forma sistemática a ênfase na porosidade das fronteiras: na maioria dos casos, a ausência de uma definição clara contribuiu para a manutenção da dicotomia, já que a definição utilizada pelo Estado, como dissemos, sempre ratificava a definição comum. Ora, é evidente que na grande maioria das pequenas cidades das New South Wales a fronteira era claramente desenhada e a operação de uma colour bar restringia fortemente o campo de possibilidades para aqueles classificados como aborígenes.

Apesar das distintas precauções tomadas para "desnaturalizar" a ideia de identidade aborígene, não podemos negar, portanto, que esta classificação 
tenha se cristalizado e que tenha tido uma inegável força de constrangimento para muitos indivíduos. Parece-me essencial, de fato, insistir tanto sobre a "realidade das construções sociais", quanto sobre a "construção social da realidade". Trata-se finalmente de "conter o construtivismo no domínio das estruturas sociais", a fim de não se negligenciar "o que, na atividade social, é percebido como uma ordem natural, cristalizada". ${ }^{38}$

Recebido em 07 de junho de 2008

Aprovado em 02 de novembro de 2008

Traduzido por Roberta Ceva

Bastien Bosa é professor de antropologia na Universidad del Rosario (Bogotá, Colômbia). E-mail: < bastien.bosa@ens.fr>

\section{Notas}

${ }^{1}$ Editada antes da Guerra de Secessão pelos estados do sul dos Estados Unidos, esta lei atribuía a todas as pessoas que supostamente tinham origem africana a categoria "negro". Para maiores detalhes sobre a situação americana, cf. sobretudo Davis (1991).

${ }^{2}$ A política da "Austrália branca", do início do século XX até os anos 1970, garantia a ausência de outros grupos não-brancos (com a notável exceção de uma minoria de chineses que se estabeleceram na Austrália no século XIX). Somente após a Segunda Guerra Mundial, outros imigrantes que não exclusivamente aqueles oriundos das Ilhas Britânicas foram aceitos na Austrália. Estes imigrantes (gregos e italianos em sua maioria) foram apelidados de "novos australianos" e eram considerados um grupo racial distinto (apelidados os "Wogs").

${ }^{3}$ Estes antropólogos trabalhavam na Universidade de Sydney em torno do professor Elkin. Este último era não somente a maior autoridade científica sobre os aborígenes da Austrália, mas igualmente um teórico e um advogado da política de assimilação, ocupando, aliás, a posição de vice-chairman no Board, até seu desmantelamento em 1969. Elkin encorajava seus estudantes a realizarem estudos práticos sobre as relações inter-raciais nas NSW, que poderiam colaborar com o Board em sua execução da política de assimilação. Nota-se que muitos conceitos caros à sociologia norte-americana dos anos 1940-50 (entre eles, o das "relações raciais") 
foram retomados de forma mais ou menos livre pelos antropólogos australianos (cf. em particular Calley 1957).

${ }^{4}$ A "casta" fazia referência ao "grau de sangue aborígene" (como nas expressões half-caste, quarter-caste, light-caste etc.). Ela não tem, portanto, qualquer relação com a "casta" indiana.

${ }^{5} 25$ de junho de 1937, Carta de William Cooper a Paterson, ministro do Interior do Commonwealth.

${ }^{6}$ Até 1967, os distintos estados australianos eram livres para seguir suas próprias políticas aborígenes. Em cada um deles, os aborígenes eram submetidos a leis ou a códigos específicos, mas as definições não eram as mesmas. Neste sentido, a história das relações raciais na Austrália ilustra magistralmente o caráter irregular e arbitrário das fronteiras das categorias raciais legalmente instituídas. Em particular, uma pessoa podia ser considerada "branca" em um estado e "aborígene" em outro. Nós nos centraremos aqui unicamente na situação nas NSW. Para um panorama da variedade das situações jurídicas na escala da Austrália, cf. McCorquodale (1987) e Rowley (1972).

${ }^{7}$ A adoção do Aboriginal Protection Act, em 1909, concedia poderes estatutários ao Aboriginal Protection Board e lhe confiava a gestão de todas as reservas. Ele impunha certas restrições sobre o movimento dos aborígenes; proibia a venda de álcool a estas pessoas; estabelecia certas disposições sobre o controle do aprendizado das suas crianças; autorizava a regulação do trabalho dos aborígenes; e, finalmente, permitia "o exame e o tratamento médico dos aborígenes". É necessário lembrarmos que o fato de ser considerado "aborígene" não tinha incidência sobre o estatuto de Natural Born British Subject e, em seguida, a partir de 1947, sobre aquele de cidadão australiano. Estes estatutos, no entanto, não garantiam um acesso automático a direitos (como o voto ou a seguridade social).

${ }^{8}$ No original: "any full-blooded or half-caste aboriginal who is native of Australia, and who is temporarily or permanently resident in NSW". Esta definição foi introduzida por uma emenda de 1936 (AP(A)A, 1936).

${ }^{9}$ Mais uma vez, estas observações somente valiam para as NSW: as relações entre a população aborígene e as autoridades variavam consideravelmente de um estado a outro. Notaremos, em particular, que em certos lugares existia uma divisão tripartida: os Full-Bloods e os Mixed-Bloods podiam ter estatutos jurídicos bastante diferentes. Cf. McCorquodale (1987).

${ }^{10}$ No original, "with an admixture of aboriginal blood".

${ }^{11}$ Liquor (Amendment) Act, 1905.

${ }^{12}$ APA, 1909: “'Aborígene significa qualquer full-blooded aborígene nativo da Austrália e qualquer pessoa que aparentemente tenha uma mistura de sangue 
aborígene, que concorrer para se beneficiar ou estiver se beneficiando de doação de alimentos ou de ajuda do Board ou que estiver residindo em uma reserva".

${ }^{13}$ O historiador Peter Read (2003) explica que, desde 1915, uma circular do Board informava aos administradores que, seguindo uma advertência do Crown Solicitor, a definição de nativo aborígene poderia incluir os octoroons e os quadroons. Como estes últimos formavam campos não-autorizados nas periferias das cidades, eles podiam, portanto, ser deslocados à força para as reservas. $1^{\circ}$ de setembro de 1915, NSWAPB, Circular 90, Copies of Letters sent, 1914-1927, NSWAO.

${ }^{14} \mathrm{AP}(\mathrm{A}) \mathrm{A}$, 1918. A definição principal estipulava que "'Aborígene' significa qualquer full-blooded ou half-caste aborígene nativo das NSW". Ao mesmo tempo, diversas seções aplicavam-se a todas as "pessoas que aparentemente tenham uma mistura de sangue aborígene".

${ }^{15}$ A única modificação à definição feita após 1918 foi uma emenda introduzida em 1936, que visava incluir os aborígenes dos outros estados que visitavam temporariamente as NSW: a expressão "um nativo das New South Wales" foi substituída por "um nativo da Austrália e que esteja temporária ou permanentemente residindo nas New South Wales" (AP(A)A, 1936).

${ }^{16}$ Mark Anthony Davidson (1869-1949), deputado de 1918 a 1949. Membro fundador do Australian Workers Union. Oriundo da classe operária e tendo tido somente a educação primária.

${ }^{17}$ Setembro de 1952, Relatório de Green (Trainee Welfare Officer) ao superintendente AWB sobre a estação de Cowra (visitada entre 18 de agosto e 05 de setembro de 1952) - AWBGC, NSWAO, 8/2783A, 3311. Ele acrescentou: "Eles se aproveitam simplesmente da pequena quantidade de sangue aborígene que possuem como o fazem muitos outros nas outras estações". Este tipo de comentário era, no entanto, relativamente raro, e aquele de Green talvez possa ser explicado pelo fato de ele estar em formação e desejar respeitar de modo estrito as determinações oficiais.

${ }^{18}$ Uma lista eleitoral havia sido criada em 1943 em vista da eleição de dois representantes aborígenes à Aboriginal Welfare Board. No entanto, muitos indivíduos não estavam inscritos nesta lista. Paradoxalmente, os únicos documentos oficiais específicos aos aborígenes eram os "certificados de isenção", criados eles também em 1943. De certo modo, estes certificados reconheciam que uma pessoa era aborígene, mas afirmavam que ela não devia ser tratada como tal. Uma pessoa que demandasse uma isenção reconhecia implicitamente, portanto, ser "aborígene", mesmo se não fosse oficialmente considerada como tal (no original: "deemed not to be an Aborigene or person apparently having an admixture of Aboriginal blood"). APA, 1943.

${ }^{19}$ Para um resumo da questão, cf. Wood (1998). Se, por um lado, é possível observar menções a "aborígene" nas certidões de nascimento e atestados de óbito, por outro, é impossível saber quantos aborígenes haviam sido registrados sem qualquer menção particular, e quantos simplesmente não constavam dos registros. 
${ }^{20}$ Esta situação complica, evidentemente, o trabalho do historiador que pretendesse trabalhar a partir de fontes onomásticas.

${ }^{21}$ Esta ausência de tecnologia burocrática para classificar os indivíduos, que teria permitido fixar, arquivar e controlar a identidade de todos os aborígenes (segundo o que G. Noiriel denomina a "grande partilha da carteira de identidade"), é surpreendente. Noiriel (1997:39) explica da seguinte forma "A identificação à distância praticada pela administração necessita que todos os indivíduos dependentes de um Estado nacional tenham sido anteriormente capturados pela escrita".

${ }^{22}$ Sobre a questão das práticas de identificação face a face no caso da França do Antigo Regime, cf. Denis et alli (2004).

${ }^{23}$ No fim dos anos 1930, os militantes aborígenes Jack Patten e William Fergusson retomaram este tema para denunciar o regime único da APA: "O ônus da refutação é, portanto, do acusado, contrariamente à tradicional prática da lei 'britânica'" (Ferguson \& Patten 1938). Durante os debates, o deputado Lang (antigo premier do Estado), não sem ironia, havia encaminhado uma emenda propondo que os empregadores dos aprendizes aborígenes fossem considerados culpados de maus-tratos, a não ser que provassem sua inocência. "Agora, para mostrar a podridão da coisa, eu proponho esta emenda. O que vale para uns também deve valer para os outros (What is sauce for the goose should be sauce for the gander). Que mal haveria em exigir isto do empregador? Ele não tem recibo dos salários que pagou? Ele não tem registros? Ele não pode trazê-los e apresentá-los?" (AP(A)B, 23 de junho de 1936, segunda leitura).

${ }^{24}$ Henry John Bate (1881-1967), deputado de 1926 a 1941 (Partido Nacionalista), fazendeiro, membro da APB de 1928 a 1943.

${ }^{25}$ Inversamente, ele fez valer que, de maneira eventual, caberia ao acusado provar que estava isento. Curiosamente, o Board dispunha de uma lista de isentos, mas não de aborígenes.

26 " [Seria] conduzida por observação individual das pessoas, numa tentativa de assegurar o grau de casta de seus pais e, a partir destas questões, formar uma opinião sobre a casta da pessoa que está sendo entrevistada".

${ }^{27} 3$ novembro de 1961. Nota para uso interno do Chairman da AWB - AWBGC, NSWAO, 8/2912B, 13991. Neste sentido, Elkin não colocava explicitamente em causa a classificação em si, mas antes a dificuldade em se obter um resultado preciso.

${ }^{28}$ Os resultados destes recenseamentos são analisados em maior profundidade em Bosa 2007.

${ }^{29}$ Cf. "Census Aboriginal Population, Australia, file for six states", NAA (CO), A1871, 1955/419 parte 4 . 
${ }^{30}$ O objetivo principal do Board por ocasião desta sondagem não era o de "contar" precisamente a população aborígine, mas o de obter a opinião da polícia sobre uma das seções do APA. No entanto, os policiais deviam igualmente fornecer números relativos à população aborígine de sua jurisdição.

${ }^{31}$ O recenseamento do Commonwealth de 1954 contabilizava 12.218 aborígenes; aquele do Board, de 1955, 12.350, e o da polícia, de 1957, 12.013.

${ }^{32} \mathrm{O}$ historiador Peter Read (2003) nota que muitos aborígenes se recusavam a declarar-se como tais ao Estado, com medo de terem suas crianças afastadas de sua companhia. De modo mais geral, os indivíduos que se identificavam como "brancos" se beneficiavam de algumas vantagens em termos de menor discriminação e oportunidades mais numerosas.

${ }^{33}$ Devido a uma relativa incerteza nas definições, bem como de uma ausência de mecanismos precisos para identificar os indivíduos.

${ }^{34}$ Se a questão do franqueamento da fronteira categorial aparece inegavelmente como um tema central no contexto australiano, o uso da noção de passing deve ser problematizado: de fato, este termo faz referência ao contexto norte-americano, no qual, desde os anos 1930, foram realizados trabalhos de sociologia abordando esta questão. Este problema mereceria um trabalho comparativo mais aprofundado, tanto no que diz respeito aos usos do termo em si, quanto das interpretações que eram feitas. Cf. Burma 1946 e Day 1932.

${ }^{35} 11$ de julho de 1952, Carta de Stratton, Manager, CTI, ao Superintendent, AWB.

${ }^{36}$ Precisamente porque estes casos eram raros, Dominguez (1994:8) sugere que podemos conservar uma perspectiva construtivista sem, contudo, focar unicamente nos casos de "franqueamento de fronteiras".

${ }^{37}$ Em trabalho de doutorado, mostramos que uma outra consequência desta situação é que a identificação aparece como extremamente dependente dos contextos locais, o que conviria reconstituir por meio de uma análise minuciosa, cidade por cidade.

${ }^{38}$ Estas expressões são tomadas de empréstimo de Avanza e Laferté (2005:139). Como já dissemos, Virginia Dominguez (1994:xiv) fazia observações semelhantes sobre as questões raciais. 


\section{Referências bibliográficas}

AVANZA, Martina \& LAFERTÉ, Gilles. 2005.

“Dépasser la 'construction des identités'? Identification, image sociale, appartenance". Genèses, 61:154-167.

BECKETT, Jeremy. 1965. "Kinship, Mobility and Community among part-Aborigines in rural Australia". International Journal of Comparative Sociology, 6(1):7-23.

BELL, James. 1965. "The part-Aborigines of NSW: three contemporary social situations". In: R. Berndt et alli (eds.), Aboriginal man in Australia. Sydney: Angus and Robertson. pp.396-418.

BURMA, John H. 1946. "The measurement of negro 'passing'". American Journal of Sociology, 52:18-22.

BRIGGS-SMITH, Noeline. 1997. Winanga Li. To remember. Moree: Northern Regional Library and Information Service.

CALLEY, Malcolm. 1957. "Race relations on the north coast of NSW". Oceania, 27(3):190-209.

CHESTERMAN, John \& GALLIGAN, Brian. 1998. Citizens without rights. Melbourne: Cambridge University Press.

DAVIS, James F. 1991. Who is black, one nation's definition. University Park: The Pennsylvania State University Press.

DAY, Caroline Bond. 1932. A study of some Negro-White families in the US. Cambridge: Harvard African Studies, X

DENIS, Vincent \& MILLOT, Vincent. 2004. "Police et identification dans la France des lumières". Genèses, 54:4-27.

DOMINGUEZ, Virginia. 1994 [1986]. White by definition: social definition in creole Lousianna. New Brunswick, NJ: Rutgers University Press.

FINK, Ruth. 1957. "The cast barrier - an obstacle to the assimilation of partaborigines in the Nort-West NSW". Oceania, 28(1):100-110.

GRAY, Geoffrey. 1999. "The Sydney scho- ol seem to view the Aborigines as forever unchanging, southeastern Australia and Australian anthropology". Aboriginal History, 24:176-200.

KERTZER David \& AREL, Dominique. 2002. Census and identity: the politics of race, ethnicity and gender in national censuses. Cambridge: Cambridge University Press.

McCORQUODALE, John. 1987. Aborigines and the law: a digest. Canberra: Aboriginal Studies Press for the Australian Institute of Aboriginal Studies.

NOIRIEL, Gérard. 1997. "Représentation nationale et catégories sociales". Genèses, 26:25-54.

PATTEN, John Thomas \& FERGUSON, William. 1938. Aborigines claim citizen rights!: a statement of the case for the Aborigines Progressive Association. Sydney: The Publicist.

READ, Peter. 1980. "Fathers and sons: a study of five men of 1900". Aboriginal History, 4(1):97-116.

- 2003. "How many separated Aboriginal children?". The Australian Journal of Politics and History, 49(2):155-163.

REAY, Marie. 1949. "Native thought in rural NSW". Oceania, 20(2):89-118. ROWLEY, Charles D. 1972. "Who is an Aboriginal? The answer in 1967". In: The destruction of Aboriginal society. Melbourne: Penguin. pp. 341-64.

SAADA, Emmanuelle. 2002. "The empire of law : dignity, prestige and domination in the colonial situation". French Politics Culture and Society, 20(2):98-120.

WOOD, Marilyn. 1998. "Nineteenth century bureaucratic constructions of indigenous identities in NSW". In: Nicolas Peterson \& Will Sanders (eds.), Citizenship and indigenous australians: changing conceptions and possibilities. New York: Cambridge University Press. pp. 35-54. 
Resumo

Este artigo versa sobre a existência de uma ordem segregada e o funcionamento da categoria "aborígene" no Sudeste da Austrália ao longo do século XX. Para além das definições "oficiais" da população aborígene, analisaremos as modalidades práticas da identificação, graças particularmente a uma análise dos recenseamentos e das classificações estatísticas dos aborígenes. Mostraremos que, na ausência de documentos oficiais especialmente reservados aos aborígenes atestando seu registro em um cadastro central, as técnicas relativas à sua identificação aproximavam-se das formas pré-industriais de reconhecimento das pessoas, fundadas na familiaridade e nas relações face a face. Esta situação tinha como consequência que aqueles localmente conhecidos como aborígenes ou que tinham traços físicos aborígenes facilmente reconhecíveis encontravamse presos em um sistema coercitivo do qual era difícil escapar, enquanto outros podiam passar através das malhas identificatórias sem, no entanto, recolocar em causa um sistema de relações raciais marcadamente dicotômico.

Palavras-chave Aborígenes, Austrália, Identificação, Raça, Classificações jurídicas.

\section{Abstract}

This article concerns the existence of a segregated order and the functioning of the category of "aborigine" in South-western Australia during the 20th century. Looking beyond the "official" definitions of the aboriginal population, we will analyse the practical modalities of identification, particularly through an analysis of the census and the statistical classifications of the Aborigines. We will show that, in the absence of official documents specifically geared towards the aborigines, attesting to their register in a central file, the techniques concerning their identification resembled pre-industrial forms of recognizing people, based on familiarity and on face-to-face relations. A consequence of this situation is that those people who were locally known to be aborigines, or who had physical traits that were readily identified as being aboriginal, found themselves caught in a coercitive system from which it was difficult to escape, whereas others were able to pass through the identificatory mesh without, in so doing, placing in check a markedly dichotomous system of racial relations.

Key words: Aborigines, Australia, Identification, Race, Legal classifications 